\title{
Purification, Characterization and Properties of Carboxylesterase from the Midgut of the Silkworm, Bombyx mori L.
}

\author{
K. R. SIDDALINGA MURTHY,* PATNAGERE S. VEERABHADRAPPA*†
}

Received 23 June 1995; revised and accepted 2 November 1995

\begin{abstract}
A carboxylesterase has been purified from the midgut of the silkworm Bombyx mori L. by a combination of ammonium sulphate fractionation, DEAE-cellulose ion-exchange chromatography, Sephacryl S-200 gel-filtration and preparative polyacrylamide gel electrophoresis (PAGE). The homogeneity of the enzyme was established by PAGE, isoelectricfocusing (IEF) and SDS-PAGE. The enzyme consists of two identical subunits with a subunit molecular weight of 72,000. The two subunits are held by non-covalent bonds. Amino acid analysis of the purified enzyme revealed a high content of hydrophobic amino acid residues. It lacks proline and tryptophan residues and free thiol groups. The data from substrate specificity study in conjunction with kinetic parameters indicate the hydrophobic nature of the active site.
\end{abstract}

Silkworm Bombyx mori L. Carboxylesterase Purification and properties Active site and enzyme kinetics

\section{INTRODUCTION}

The silkworm, Bombvx mori L., belongs to the family Bombycidae and order Lepidoptera. It is a commercially important domesticated insect producing silk and routinely feeds on the leaves of the mulberry, Morus album. The potential hazard faced in sericulture is the occasional contamination of the mulberry leaves by air-borne insecticides that have been used in neighbouring fields. Thus, silkworm can be cited as a non-target species and should be protected from harmful contaminations. Studies on the effect of insecticides on silkworm are conducted to discover their interaction with the enzymes-esterases.

Esterases are classified as hydrolases (Dixon and Webb, 1979), a large and diverse group of enzymes which catalyze the hydrolysis of a wide range of aliphatic and aromatic esters, choline esters and organophosphorus compounds. Carboxylesterases, the false target enzymes of insecticides, have both broad substrate specificities and distribution in the tissues of most organisms (Meyers, 1960; Krisch, 1971; Walker and Mackness, 1983). Carboxylesterases hydrolyse aliphatic and aromatic esters, as well as amides and thioesters, and are important in the metabolism of xenobiotics of the ester or amide type (Krisch, 1971; Dudman and Zerner, 1975;

\footnotetext{
*Department of Chemistry, Central College, Bangalore University, Bangalore 560001 , India.

$\dagger$ Author for correspondence.
}

Fonnum et al., 1985; Oppenoorth, 1985; Junge and Krisch, 1975). These carboxylesterases are shown to act as scavangers of pesticides and it has been found that in Myzus persicae, they hydrolyse the pesticide very slowly (Devonshire and Moores, 1989). However, in many other insects their function remains uncertain.

Examination of different tissues of the 5-day old 5th instar larvae revealed carboxylesterase as the predominant enzyme in all tissues and especially in the midgut (Siddalinga Murthy, 1991). Since carboxylesterase is one of the enzymes implicated in detoxification of pesticides in addition to its other role in metabolizing fatty acid esters, the present paper deals with silkworm midgut carboxylesterase.

\section{MATERIALS AND METHODS}

\section{Silkworm}

The silkworm larvae, (B. mori) were reared in the Department of Sericulture, Central College, Bangalore University, Bangalore 560 001, by feeding unlimited amounts of $M$. album leaves. Five-day old 5th instar larvae were used in the present investigation.

\section{Chemicals}

The organophosphorus inhibitors, diethylphosphofluoridate (DEF), dichlorvos, phosphamidon, mevinphos were gifts from Pesticide and Industrial Chemical 
Repository (MD-8), Research Triangle Park, North Carolina, U.S.A. Paraoxon and carbaryl were obtained from Chem Service Inc., West Chester, PA, U.S.A. Eserine sulphate, neostigmine bromide, $p$-chloromercuribenzoate (PCMB), Sephadex G-200, Sephacryl S-200 and all the substrates were purchased from Sigma Chemical Company, St Louis, MO, U.S.A. DEAE-cellulose $(0.7 \mathrm{mEq} / \mathrm{g})$ was obtained from Schleicher and Schull, GmbH, D3354, Dassel, Germany. The ampholyte carrier ( $\mathrm{pH} \mathrm{4-6)}$ was purchased from Serva-Fein Biochemica, Heidelberg, Germany.

\section{Enzyme assay}

Carboxylesterase activity was determined using 1naphthyl esters as substrates according to the method of Gomori (1953) as modified by van Asperen (1962). Carboxylesterase activity was also determined using $p$-nitrophenyl esters as substrates according to the method of Hoejring and Svensmark (1976). One unit of enzyme activity was defined as the amount of enzyme that liberated $1 \mu \mathrm{mol}$ product/min at $\mathrm{pH} 7.0$ and $27^{\circ} \mathrm{C}$.

\section{Alternate product inhibition}

Alternate product inhibition experiments were performed by varying the concentration of 1-naphthyl butyrate while maintaining a constant $\mathrm{pH}$ of 7.0 and constant concentration of either $p$-nitrophenol, acetic acid or propionic acid. The enzyme was preincubated with the alternate product for $30 \mathrm{~min}$ at $27^{\circ} \mathrm{C}$ and then assayed for esterase activity.

Protein was estimated quantitatively by the method of Lowry et al. (1951), using bovine serum albumin (BSA) as standard. The protein concentration in the eluent fractions obtained from chromatographic columns were routinely monitored by measuring absorbance at $280 \mathrm{~nm}$.

\section{Electrophoresis}

PAGE was carried out, essentially according to the method of Davis (1964) and Ornstein (1964). A discontinuous gel system, containing $10 \%$ separating gel and $4.5 \%$ spacer gel, was used. The electrode chambers were filled with electrode buffer, $0.05 \mathrm{M}$ glycine-sodium hydroxide, $\mathrm{pH}$ 8.9. An aliquot of the enzyme extract suitably diluted with $20 \%$ sucrose solution containing $2 \mu 1$ of bromophenol blue was carefully layered onto each gel and electrophoresed for $2 \mathrm{~h}$ at $10^{\circ} \mathrm{C}$ maintaining a current of $2 \mathrm{~mA}$ per gel.

\section{Staining for esterase activity and protein}

Esterase activity was detected on PAGE and IEF gels by the method of Hunter and Markert (1957). The electrophoresed gels were placed in $100 \mathrm{ml}$ of $0.1 \mathrm{M}$ sodium

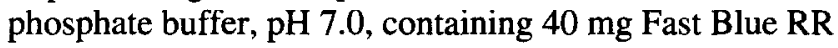
salt and $20 \mathrm{mg} 1$-naphthyl acetate in $1 \mathrm{ml}$ acetone, for $15 \mathrm{~min}$ at $37^{\circ} \mathrm{C}$. Although 1-naphthyl butyrate was the preferred substrate, the number of esterase bands revealed were the same when 1-naphthyl acetate was used as substrate. Hence, 1-naphthyl acetate was used as substrate for studies using PAGE. The gels were stored in $7.5 \%$ acetic acid.

Proteins were detected on the gels (PAGE and SDSPAGE gels) by staining with $0.25 \%$ coomassie brilliant blue R-250 in a solution containing $45 \%$ methanol and $10 \%$ acetic acid for $1 \mathrm{~h}$. The gels were destained by leaching with a solution containing $5 \%$ methanol and $7.5 \%$ acetic acid. The gels were then stored in $7.5 \%$ acetic acid.

Protein was detected in the IEF gels by the method of Vesterberg et al. (1977). The protein in the gel was fixed by soaking in fixing solution $(18.6 \mathrm{ml}$ water, $0,9 \mathrm{~g}$ sulphosalicylic acid and $3.0 \mathrm{~g}$ trichloroacetic acid) for 30 min at $60^{\circ} \mathrm{C}$. The gel was then stained using Coomassie brilliant blue G-250 (7.5 ml of $70 \%$ perchloric acid was added with vigorous stirring to $200 \mathrm{ml}$ water containing $100 \mathrm{mg}$ Coomassie brilliant blue G-250) for $30 \mathrm{~min}$ at $60^{\circ} \mathrm{C}$.

\section{UV spectrum}

The UV absorption spectra of the purified enzyme preparation $(125 \mu \mathrm{g} / \mathrm{ml})$ was recorded in a UV-vis recording spectrophotometer in $0.1 \mathrm{M}$ sodium phosphate buffer, pH 7.0 and $0.1 \mathrm{~N}$ sodium hydroxide solution.

\section{Purification}

The larvae were dissected and the midgut slit open to remove the digestive juice and mulberry leaves. The midgut was rinsed with cold $0.1 \mathrm{M}$ sodium phosphate buffer, $\mathrm{pH} 7.0$, stored at $-20^{\circ} \mathrm{C}$ until use. About 150 larvae yielded $50 \mathrm{~g}$ of midgut tissue. The tissue $(50 \mathrm{~g})$ was homogenized using an all-glass Potter-Elvehjem homogenizer in five batches, taking $10 \mathrm{~g}$ at a time in $2 \mathrm{vol}$. of $0.05 \mathrm{M}$ sodium phosphate buffer, $\mathrm{pH} 7.0$. The extract was centrifuged at $7500 \mathrm{~g}$ for $20 \mathrm{~min}$ at $4^{\circ} \mathrm{C}$. The supernatant from all five batches were pooled and used as the crude enzyme extract.

\section{Ammonium sulphate precipitation}

Ammonium sulphate precipitation $(30-80 \%)$ was carried out at $4^{\circ} \mathrm{C}$, and the precipitate obtained was centrifuged at $7500 \mathrm{~g}$ for $20 \mathrm{~min}$ in the cold. The precipitate was then dissolved in $30 \mathrm{ml}$ of $0.05 \mathrm{M}$ sodium phosphate buffer, pH 7.0 and dialyzed with three changes of the same buffer. The precipitated proteins were removed by centrifugation at $7500 \mathrm{~g}$ for $20 \mathrm{~min}$ in cold.

\section{Ion-exchange chromatography on DEAE-cellulose}

The 30-80\% dialyzed ammonium sulphate fraction was applied onto DEAE-cellulose column $(160 \times$ $23 \mathrm{~mm}$ ), equilibrated with $0.05 \mathrm{M}$ sodium phosphate buffer, $\mathrm{pH} 7.0$ (starting buffer). Usually Tris buffer is used with anion exchange chromatography. However, in the present investigation Tris buffer was found to interfere with the assay of the enzyme activity. Hence, phosphate buffer was preferred among other buffers tested. The column was washed with $150 \mathrm{ml}$ of starting buffer, containing $0.25 \mathrm{M}$ sodium chloride and fractions of 
$10 \mathrm{ml}$ were collected at a flow rate of $30 \mathrm{ml} / \mathrm{h}$. The washing was followed by elution with starting buffer, containing $0.6 \mathrm{M}$ sodium chloride. One peak of esterase activity was eluted in the washing and the second with $0.6 \mathrm{M}$ sodium chloride. The peak fractions were designated as DEAEC-I and DEAEC-II respectively and pooled separately.

\section{Concentration of DEAEC-II}

The pooled DEAEC-II fraction, containing carboxylesterase, was diluted five-fold with the starting buffer and adsorbed onto a DEAE-cellulose column $(25 \times 10 \mathrm{~mm})$. The bound proteins were eluted by passing starting buffer, containing $0.6 \mathrm{M}$ sodium chloride. By this method, the sample was concentrated to $5.0 \mathrm{ml}$.

\section{Gel-filtration on Sephacryl S-200}

The concentrated fraction obtained was applied onto the Sephacryl S-200 column $(710 \times 9 \mathrm{~mm})$ and eluted with starting buffer, containing $0.25 \mathrm{M}$ sodium chloride. Fractions of $2.0 \mathrm{ml}$ were collected at a flow rate of $6 \mathrm{ml} / \mathrm{h}$. Two protein peaks obtained were named as SephI fraction (high molecular weight) and Seph-II fraction (low molecular weight). The Seph-I fraction, containing all the esterase activity, was concentrated using DEAEcellulose as described earlier. The concentrated fraction was desalted by passing through Sephadex G- 25 column $(100 \times 10 \mathrm{~mm})$, equilibrated in $0.05 \mathrm{M}$ sodium phosphate buffer, pH 7.0.

\section{Preparative polyacrylamide gel electrophoresis}

Preparative polyacrylamide slab gel electrophoresis was carried out according to the method of Davis (1964) and Ornstein (1964) in $8 \%$ separating gel $(13.5 \times 11 \times$ $0.35 \mathrm{~cm})$ and $4.5 \%$ spacer gel. The concentrated and desalted Seph-I fraction $(4.0 \mathrm{ml})$ containing $20 \%$ glycerol and bromophenol blue was loaded above the gel and electrophoresed at $4^{\circ} \mathrm{C}$ for $7 \mathrm{~h}$ at 100 volts using $0.05 \mathrm{M}$ glycine-sodium hydroxide buffer, $\mathrm{pH}$ 8.9. After the completion of electrophoresis, the gel was stained for esterase activity using 1-naphthyl acetate as substrate. The gel was then washed with water and the stained portion of the gel containing esterase band was sliced and homogenized with $5 \mathrm{ml}$ of cold $0.05 \mathrm{M}$ sodium phosphate buffer, $\mathrm{pH} 7.0$, containing $0.25 \mathrm{M}$ sodium chloride. The homogenate was centrifuged in cold at $7,500 \mathrm{~g}$ for 20 $\min$. The residue was then resuspended (twice) in extraction buffer, homogenized and centrifuged. The pooled supernatant was concentrated using DEAE-cellulose as described above.

\section{Molecular weight determination}

\section{SDS-PAGE method}

SDS-PAGE was carried out on $10 \%$ gels according to the method of Laemmli (1970) using standard proteins. The molecular weight of the carboxylesterase was derived from the plot of $\log$ molecular weight vs relative mobility.

\section{Gel-filtration method}

The molecular weight of the purified carboxylesterase was estimated by gel-filtration on Sephadex G-200 according to the method of Andrews (1970). The Sephadex column was equilibrated with $0.05 \mathrm{M}$ sodium phosphate buffer, $\mathrm{pH} 7.0$, containing $0.25 \mathrm{M}$ sodium chloride and eluted with the same buffer at a flow rate of $4 \mathrm{ml} / \mathrm{h}$ at $4^{\circ} \mathrm{C}$.

\section{Amino acid analysis}

Amino acid analysis was carried out according to the method of Moore and Stein (1963). The enzyme was hydrolysed in an evacuated and sealed tube for $24 \mathrm{~h}$ at $110^{\circ} \mathrm{C}$ in $2 \mathrm{ml}$ of $6 \mathrm{M}$ hydrochloric acid. Amino acid analysis was carried out in an automated amino acid analyser equipped with an automatic data system. Free thiol groups in the enzyme were estimated according to the method of Ellman (1959) by reaction with (DTNB) 5,5'dithiobis-(2-nitrobenzoic acid).

\section{IEF}

IEF was performed by the method of Wringley (1969) on $7.5 \%$ polyacrylamide gels using ampholyte carrier, pH 4-6. The upper electrode chamber was filled with $0.01 \mathrm{M}$ histidine and the lower cathode chamber with $0.01 \mathrm{M}$ glutamic acid (Pharmacia, 1982). The electrofocusing was performed at $4{ }^{\circ} \mathrm{C}$ and the current was maintained at $2 \mathrm{~mA} / \mathrm{gel}$ tube $(1.5 \mathrm{~h})$. After electrofocusing, the gels were stained for esterase activity and protein.

\section{Effect of $p H$ and $p H$ stability}

The enzyme was incubated in different buffers of $\mathrm{pH} \mathrm{4.0-9.5} \mathrm{for} 30 \mathrm{~min}$ at room temperature and assayed for esterase activity at $27^{\circ} \mathrm{C}$ using 1-naphthyl butyrate in different buffers of $\mathrm{pH} 4.0-9.5$. The $\mathrm{pH}$ stability was studied by incubating the enzyme for $24 \mathrm{~h}$ at $27^{\circ} \mathrm{C}$ in different buffers of $\mathrm{pH} 4.0-11.0$ and assaying with $0.1 \mathrm{M}$ sodium phosphate buffer, $\mathrm{pH} 7.0$.

\section{Effect of temperature and thermal stability}

The enzyme was incubated at different temperatures between 10 and $60^{\circ} \mathrm{C}$ for $20 \mathrm{~min}$ and assayed each time, at the same temperature, using 1-naphthyl butyrate. The temperature stability was studied by incubating the enzyme at different temperatures between 20 and $60^{\circ} \mathrm{C}$ for different intervals of time followed by rapid cooling to $0^{\circ} \mathrm{C}$. The enzyme was then assayed at $27^{\circ} \mathrm{C}$.

\section{Energy of activation}

The energy of activation was determined at temperatures between 5 and $65^{\circ} \mathrm{C}$ using the Arrhenius plot.

\section{Inhibitor specificity}

The enzyme was preincubated with different concentrations of inhibitor $\left(10^{-3}-10^{-9} \mathrm{M}\right)$ for $30 \mathrm{~min}$ at $27^{\circ} \mathrm{C}$. 
Then the enzyme was assayed using 1-naphthyl butyrate as substrate. Stock solutions of different inhibitors were dissolved in $1 \mathrm{ml}$ acetone and then made up to $10 \mathrm{ml}$ with $0.05 \mathrm{M}$ sodium phosphate buffer, $\mathrm{pH} 7.0$, containing $0.2 \mathrm{M}$ sodium chloride and $5 \%$ dimethysulphoxide.

\section{RESULTS}

\section{Enzyme purification}

Table 1 summarizes the procedure for purification of an enzyme beginning with $50 \mathrm{~g}$ of midgut tissue. The average overall purification was 370 -fold and the yield was $65 \%$. The elution profile of ion-exchange and gelfiltration chromatography on DEAE-cellulose and cryl S200 are depicted in Figs 1 and 2, respectively. Ionexchange chromatography of crude esterase preparation on DEAE-cellulose at $\mathrm{pH} 7.0$ gave two esterase fractions, DEAEC-I and DEAEC-II (Fig. 1) accounting for 10 and $90 \%$ of the total activity, respectively. The gel electrophoretic analysis performed for crude and the two DEAEC-fractions are shown in Fig. $3[\mathrm{i}(\mathrm{A}, \mathrm{B}$ and $\mathrm{C})]$, respectively. DEAEC-II was further purified by gel-filtration on Sephacryl S-200 (Fig. 2). The Seph-I fraction, containing all the activity, is subjected to gel electrophoresis, the pattern of which is shown in Fig. 3[i (D)]. The Seph-I fraction was purified to homogeneity by preparative PAGE.

\section{Criteria of homogeneity}

The homogeneity of the purified fraction was established by PAGE [Fig. 3 (ii)A and B] and isoelectric focusing [Fig. 3(iii) A and B]. SDS-PAGE revealed only one band, both in presence and absence of dithiothreitol (DTT), as shown in Fig. 3[iv (A and B)].

\section{Substrate specificity}

The rate of hydrolysis of a number of esterase substrates by the midgut carboxylesterase was measured (Table 2). Naphthyl esters were more readily hydrolyzed than $p$-nitrophenyl esters, with naphthyl butyrate being the preferred substrate. The enzyme hydrolyzed 2-naphthyl acetate at a lower rate compared to that of 1-naphthyl acetate. The enzyme did not hydrolyze acetylthiocholine, and thus it is unlikely to have any acetylcholinesterase activity (Ellman, 1959). The esterase preparation also did not show any phosphatase activity. The enzyme lacked proteolytic activity as shown by its inability to hydrolyze casein (Kunitz, 1947).

\section{Inhibitor specificity}

One of the accepted classifications of esterases is by their inhibition properties (Meyers, 1960; Krisch, 1971; Walker and Mackness, 1983). Carboxylesterases are known to be serine hydrolases and therefore are strongly inhibited by organophosphorus compounds. The purified esterase, when incubated with different concentrations of dichlorvos, paraoxon, mevinphos, phosphamidon and DEF, and the percent inhibition plotted against pI (negative logarithm of molar inhibitor concentration) gave a single sigmoid curve in each case, as illustrated for dichlorvos (Fig. 4). Complete inhibition was noticed at $\mathrm{p} / 3\left(1 \times 10^{-3} \mathrm{M}\right)$. On the other hand, the esterase was found to be relatively resistant when treated with carbamates (carbaryl, neostigmine bromide and eserine sulphate) and sulphydryl inhibitor (PCMB).

\section{Molecular properties}

\section{Molecular weight}

The molecular weight of the carboxylesterase estimated by SDS-PAGE, both in presence and absence of DTT, was found to be 72,000 (Fig. 5). Molecular weight, determined by gel-filtration using Sephadex G-200, gave a value of 144,540 (Fig. 6). However, a molecular weight of 72,000 was obtained by gel-filtration on Sephadex G200 in the presence of $8 \mathrm{M}$ urea. The Stokes radius was found to be $4.35 \mathrm{~nm}$.

\section{Amino acid analysis}

The result of amino acid analysis of the purified carboxylesterase, expressed as residue/mol of enzyme is given in Table 3 . The enzyme contained 1324 amino acid residues and the molecular weight calculated on the basis of amino acid composition was found to be 143,150 . The enzyme had a high content of hydrophobic amino acid residues $(32.7 \%)$. The enzyme was found to be lacking in proline residues. The alkaline absorption spectrum did not show any peak around $290 \mathrm{~nm}$ indicating the absence of tryptophan residues. No free thiol groups were detectable as determined by the test for thiol groups with DTNB (Ellman, 1959). The enzyme was not a glycoprotein as it did not stain with PAS reagent (Rennert, 1967).

TABLE 1. Purification of carboxylesterase from the midgut of the silkworm larvac, $B$. mori

\begin{tabular}{lcccccc}
\hline Purification step & $\begin{array}{c}\text { Total volume } \\
(\mathrm{ml})\end{array}$ & $\begin{array}{c}\text { Total protein } \\
(\mathrm{mg})\end{array}$ & $\begin{array}{c}\text { Total units } \\
(\mu \mathrm{mol} / \mathrm{min})\end{array}$ & $\begin{array}{c}\text { Specific activity } \\
(\text { units/mg protein) }\end{array}$ & Fold purification & $\%$ Yield \\
\hline Homogenate & 125 & 1229.8 & 1425.3 & 1.159 & 1.00 & 100.00 \\
$80 \%\left(\mathrm{NH}_{4}\right)_{2} \mathrm{SO}_{4}$ precipitate & 30 & 589.7 & 1350.8 & 2.291 & 1.98 & 94.77 \\
DEAEC-I & 40 & 491.4 & 144.2 & 0.293 & 10.25 & 10.12 \\
DEAEC-II & 40 & 79.6 & 1185.5 & 14.893 & 12.85 & 83.18 \\
Seph-I & 10 & 6.5 & 973.4 & 149.754 & 68.29 \\
Preparative PAGE & 5 & 2.15 & 923.5 & 429.535 & 370.61 & 64.79 \\
\hline
\end{tabular}




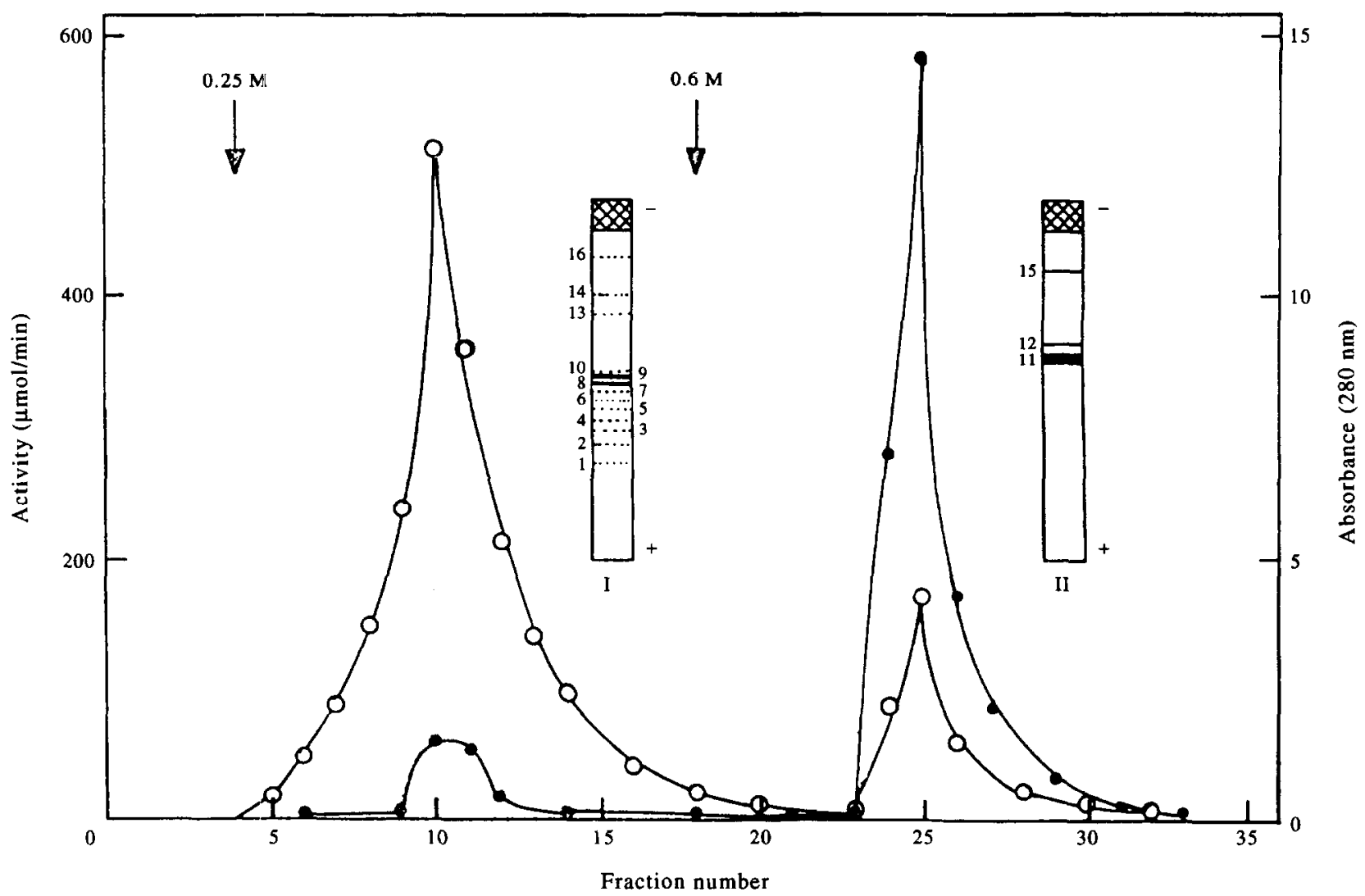

FIGURE 1. DEAE-cellulose column chromatography of ammonium sulphate fraction of midgut carboxylesterases. Protein, $(590 \mathrm{mg}$ ) was applied to $2 \times 15 \mathrm{~cm}$ column, equilibrated with $0.05 \mathrm{M}$ sodium phosphate buffer, $\mathrm{pH} 7.0$. Stepwise elution was carried out with starting buffer containing 0.25 and $0.6 \mathrm{M}$ sodium chloride at a flow rate of $30 \mathrm{ml} / \mathrm{h}$. Fractions of $5 \mathrm{ml}$ were collected and assayed for esterase activity using 1 -naphthyl butyrate as substrate $(\bullet-)$ ). Protein (0-0) was measured by absorbance at $280 \mathrm{~nm}$. The inset figures I and II correspond to the PAGE pattern of esterase zymograms of DEAEC-I and DEAEC-II, respectively.

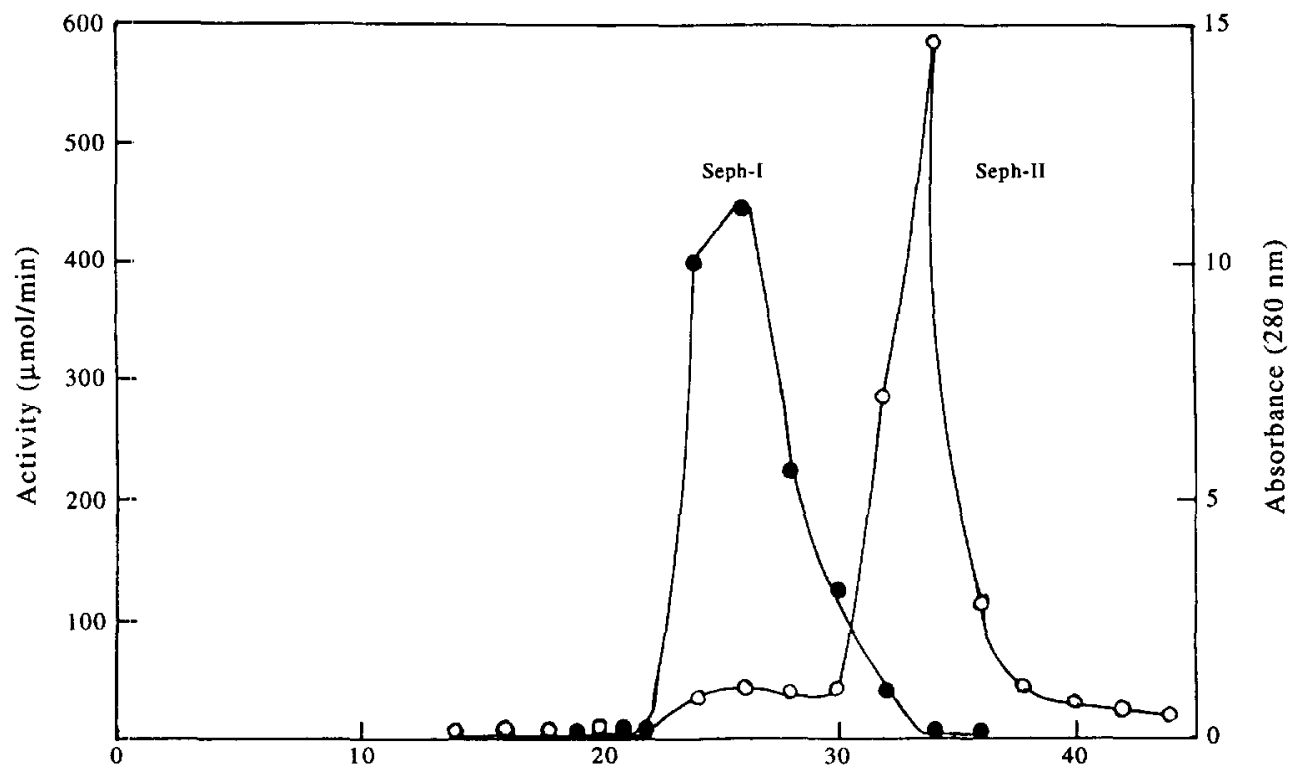

Fraction number

FIGURE 2. Sephacryl S-200 gel-filtration chromatography of DEAEC-II fraction. Concentrated protein $(80 \mathrm{mg})$ in $0.05 \mathrm{M}$ sodium phosphate buffer, $\mathrm{pH} 7.0$, containing $0.25 \mathrm{M}$ sodium chloride was applied to the column $(71 \times 0.9 \mathrm{~cm})$ and eluted with the same buffer at a flow rate of $6 \mathrm{ml} / \mathrm{h}$. Fractions of $2 \mathrm{ml}$ were collected, assayed for esterase activity $(\bullet-\bullet)$ using 1 -naphthyl butyrate as substrate and protein $(\circ-\circ)$ was measured by absorbance at $280 \mathrm{~nm}$. 


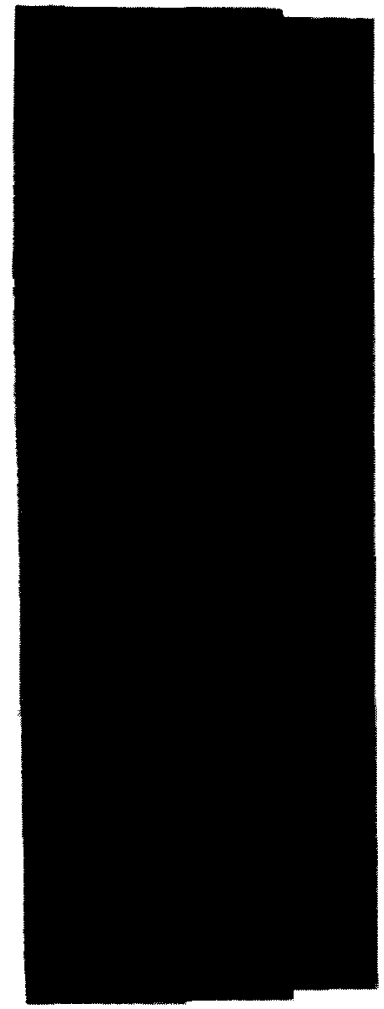

(i)

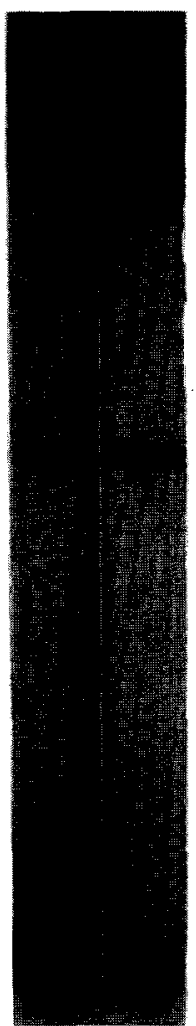

(ii)

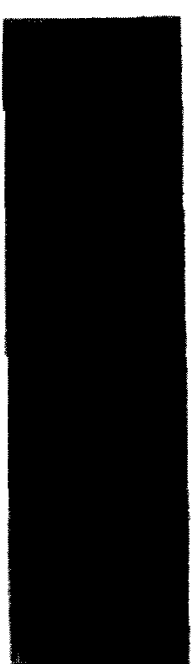

(iii)

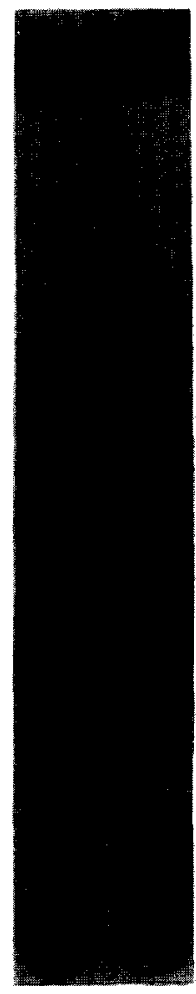

(iv)

FIGURE 3. (i) Zymograms of the midgut carboxylesterases at $\mathrm{pH}$ 8.9. (A) Ammonium sulfate fraction, (B) DEAEC-I fraction, (C) DEAEC-II fraction and (D) Seph-I fraction. (ii) Zymogram of purified carboxylesterase in 10\% gels (A) acitivity and (B) protein staining. (iii) Gel electrofocusing pattem of the purified carboxylesterase in $7.5 \%$ gels, ampholyte $\mathrm{pH}$ ranging from 4 to 6. (A) activity and (B) protein staining. (iv) SDS-PAGE pattern of the purified carboxylesterase in $10 \%$ gels. Gels were stained with Coomassie brilliant blue R-250 (A) in the absence of DTT, and (B) in the presence of DTT. The direction of migration is from cathode (top) to anode (bottom).

TABLE 2. Substrate specificity of the midgut carboxylesterase of the silkworm, B. mori

\begin{tabular}{lc}
\hline Substrate & $\begin{array}{c}\text { Enzyme activity } \\
(\mu \mathrm{mol} / \mathrm{min})\end{array}$ \\
\hline 1-naphthyl acetate & 14.32 \\
1-naphthyl propionate & 39.06 \\
1-naphthyl butyrate & 44.27 \\
1-naphthyl laurate & 0.00 \\
2-naphthyl acetate & 11.07 \\
1-naphthyl phosphate & 0.00 \\
$p$-nitrophenyl acetate & 3.36 \\
$p$-nitrophenyl propionate & 7.75 \\
$p$-nitrophenyl butyrate & 10.50 \\
\hline
\end{tabular}

\section{IEF}

The anionic nature of the esterase is indicated by the pI value of 5.2 obtained after IEF [Fig. 3(iii) A and B].

\section{Catalytic properties}

$\mathrm{K}_{m}$ and $\mathrm{V}_{\max }$

The kinetic parameters for the hydrolysis of different naphthyl and $p$-nitrophenyl esters are given in Table 4.

\section{Effect of $p H$ and $p H$ stability}

The esterase was found to be optimally active at $\mathrm{pH} 8.5$, and was highly stable in neutral and alkaline media (pH 7-10).

\section{Thermal stability}

The esterase was found to be optimally active at $45^{\circ} \mathrm{C}$, with biphasic inactivation at higher temperatures (Fig. 7). The thermal stability curve $\mathrm{T}_{7}\left(60^{\circ} \mathrm{C}\right)$ appears to be biphasic indicating that there may be two forms of the enzyme, one more labile to high temperature than the other. The activation energy of the enzyme calculated from slopes of Arrhenius plot was found to be $5.03 \mathrm{kcal} / \mathrm{mol}$.

\section{Alternate product inhibition}

Increasing concentration of $p$-nitrophenol (1-35 mM) drastically affected the activity of the enzyme. The plots of percent activity vs concentration of $p$-nitrophenol 


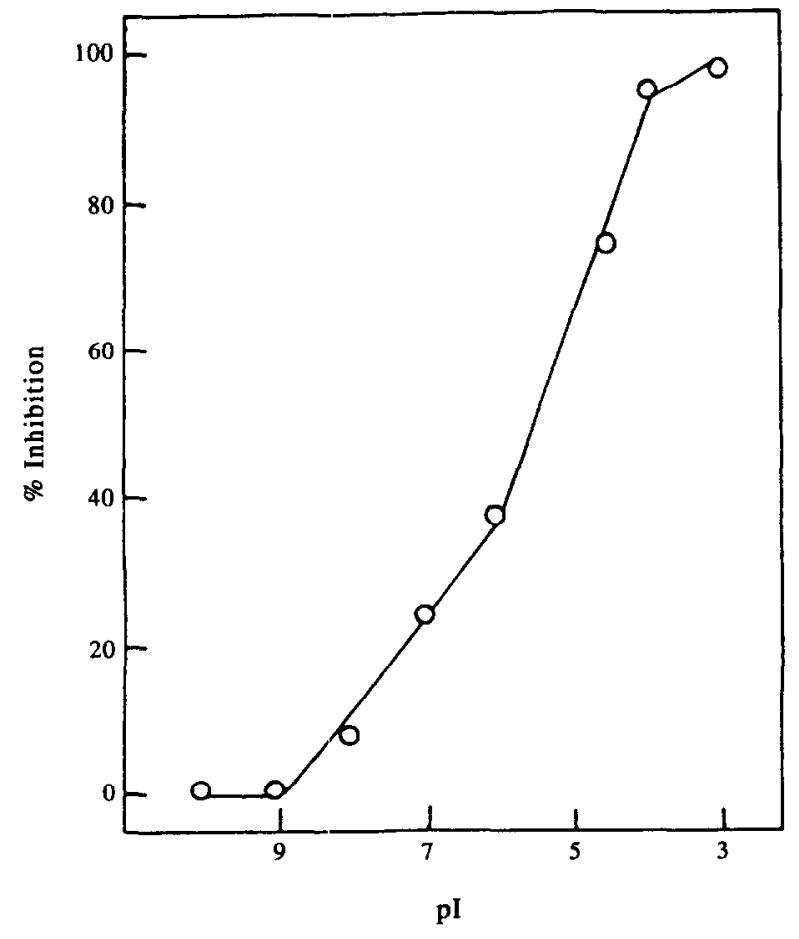

FIGURE 4. Inhibition curve for the hydrolysis of 1-naphthyl butyrate by the midgut carboxylesterase with dichlorvos.

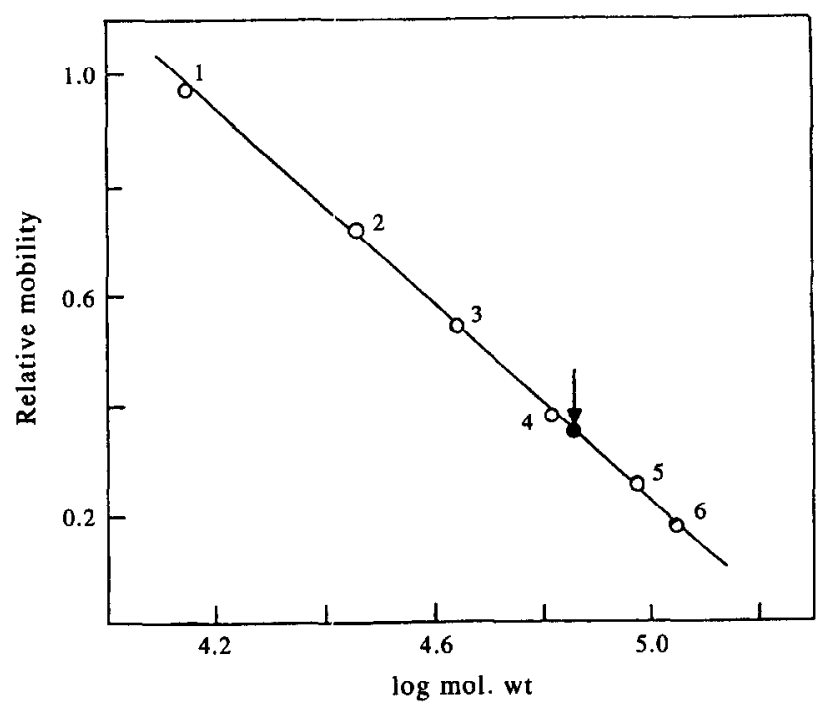

FIGURE 5. Molecular weight determination of carboxylesterase by SDS-PAGE. A plot of relative mobilities against log molecular weights. The marker proteins used were: (1) lysozyme (14,300); (2) carbonic anhydrase $(29,000)$; (3) ovalbumin $(45,000) ;(4)$ bovine serum albumin monomer $(66,000)$ : (5) phosphorylase b $(97,400)$; and (6) $\beta$ galactosidase $(116,000)$. Arrow corresponds to the midgut carboxylesterase.

showed a mild activation (almost 1.7 -fold with $10 \mathrm{mM}$ $p$-nitrophenol) of the esterase activity at low concentrations and inhibition at high concentrations (Fig. 8). The double-reciprocal plots (LB-plots) obtained at different concentrations of $p$-nitrophenol $(1-35 \mathrm{mM})$ intersected at a common point on the $1 / S$ axis, indicating that the activation (at $<10 \mathrm{mM}$ ) and inhibition $(>10 \mathrm{mM}$ ) was non-competitive (Fig. 9). An uncompetitive type of

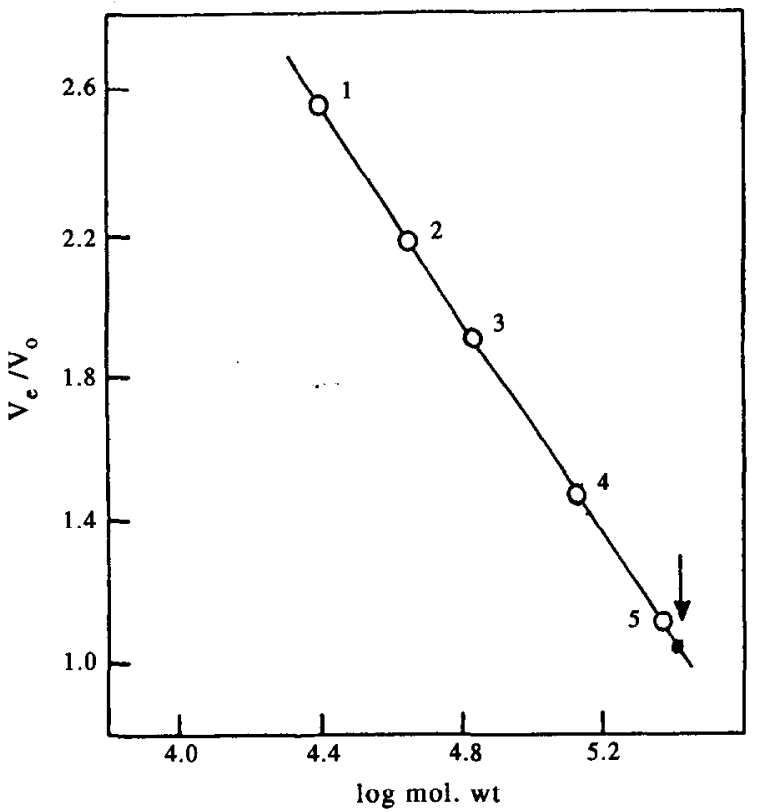

FIGURE 6. Molecular weight determination of carboxylesterase by gel-filtration on Sephadex G-200. Plot of $V_{e} / V_{o}$ against log molecular weights. The marker proteins used were: (1) cytochrome c $(12,400)$; (2) chymotrypsinogen $(25,000)$; (3) ovalbumin $(45,000)$; (4) bovine serum albumin monomer $(66,000)$; and (5) bovine serum albumin dimer $(132,000)$. Arrow indicates the elution position of the purified carboxylesterase.

TABLE 3. Amino acid composition of the midgut carboxylestease of the silworm larvae, $B$. mori

\begin{tabular}{lc}
\hline Amino acid & Total number of residues/mol \\
\hline ASx & 189 \\
Glx & 135 \\
Ser & 162 \\
Gly & 162 \\
His & 27 \\
Arg & 81 \\
Thr & 54 \\
Ala & 81 \\
Tyr & 54 \\
Val & 81 \\
Met & 27 \\
l/2 Cys & 28 \\
Ile & 81 \\
Leu & 81 \\
Phe & 54 \\
Lys & 27 \\
Trp & - \\
Cys & \\
Total & - \\
\hline
\end{tabular}

*Trp content was estimated from the alkalaine UV spectra.

"Free thiol groups estimated by Ellman method (1959).

inhibition was observed with acetic and propionic acid. The replots of slopes of the LB plots vs concentration of alternate products, $p$-nitrophenol, acetic and propiionic acid gave linear lines, with an inhibition constant $\left(K_{i}\right)$ of 10,12 and $40 \mathrm{mM}$, respectively. 
TABLE 4. $K_{\mathrm{m}}$ and $V_{\max }$ for the midgut carboxylesterase of the silkworm, $B$. mori

\begin{tabular}{lcc}
\hline Substrate & $K_{\mathrm{m}}(\mu \mathrm{M})$ & $\begin{array}{c}V_{\max } \\
(\mu \mathrm{mol} / \mathrm{min})\end{array}$ \\
\hline 1-naphthyl acetate & 370 & 17.8 \\
1-naphthyl propionate & 143 & 27.6 \\
l-naphthyl butyrate & 55 & 38.10 \\
2-naphthyl acetate & 5000 & 14.50 \\
$p$-nitrophenyl acetate & 2860 & 13.20 \\
$p$-nitrophenyl propionate & 1050 & 18.50 \\
$p$-nitrophenyl butyrate & 400 & 26.30 \\
\hline
\end{tabular}

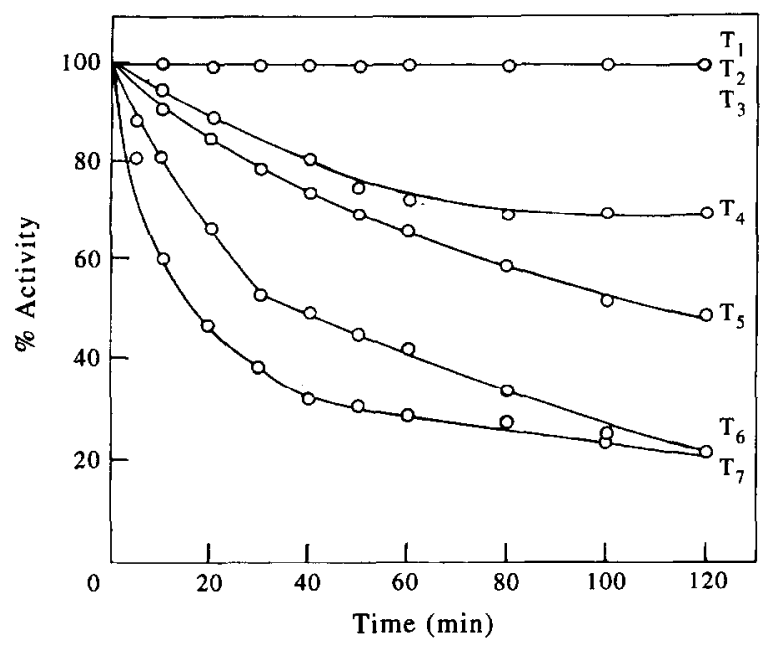

FIGURE 7. Effect of temperature on the stability of carboxylesterase. $T_{1}, 20^{\circ} \mathrm{C} ; T_{2}, 26^{\circ} \mathrm{C} ; T_{3}, 37^{\circ} \mathrm{C} ; T_{4}, 45^{\circ} \mathrm{C} ; T_{5}, 50^{\circ} \mathrm{C} ; T_{6}, 55^{\circ} \mathrm{C}$; and $T_{7}$, $60^{\circ} \mathrm{C}$.

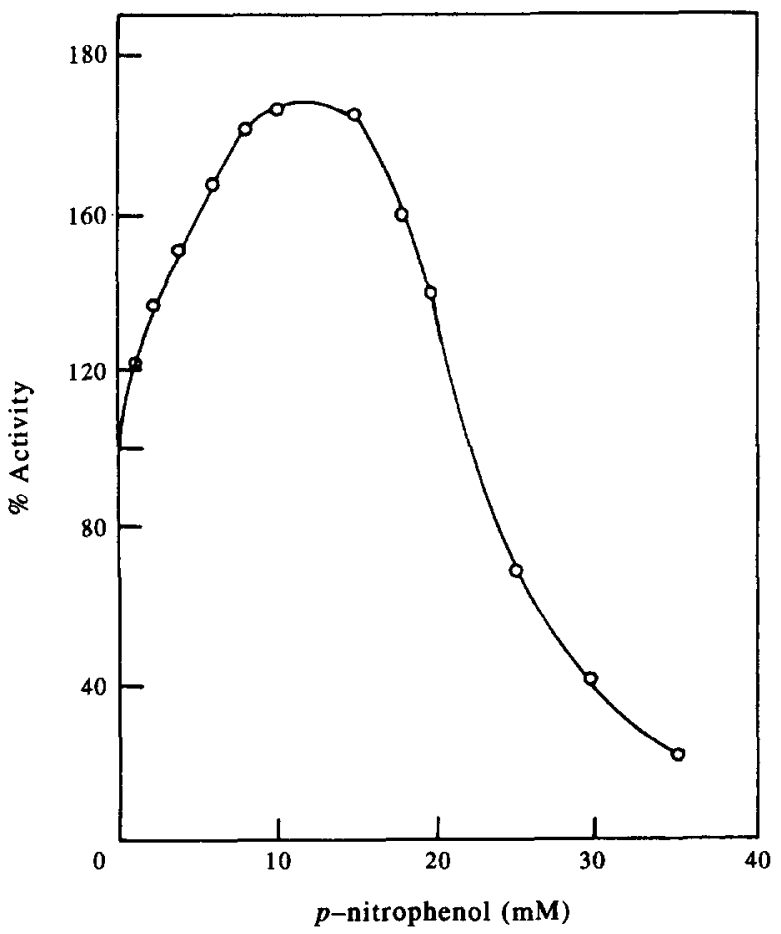

FIGURE 8. Effect of p-nitrophenol on the activity of purified carboxylesterase.

\section{DISCUSSION}

Non-specific esterases represent a large, diverse and complex group of major hydrolytic enzyme systems and possess the property of overlapping substrate specificity, hydrolysing both endogenous and exogenous esters of widely differing structures leading to problems of identification and classification (Dixon and Webb, 1979; Walker and Mackness, 1983). However, based on the sensitivity towards different classes of inhibitors and substrates, esterases were classified as carboxylesterases, cholinesterases and arylesterases (Holmes and Masters, 1967; Morikawa et al., 1976). Our studies, on the purified midgut esterase, showed complete inhibition by organophosphorus inhibitors $\left(10^{-3} \mathrm{M}\right)$ while being totally resistant towards carbamate and sulphydryl inhibitors, indicating that the enzyme is a carboxylesterase. The same criteria were used to characterize the carboxylesterases in the beetle, Haltica caerulea (Veerabhadrappa et al., 1980), in the nematode, Caenorhabditis elegans (McGhee, 1987) and in the termite, Odentotermes horni (Sreerama and Veerabhadrappa, 1991).

According to the substrate specificity studies the purified carboxylesterase seemed to possess a hydrophobic catalytic centre corresponding to the leaving group (1naphthyl and $p$-nitrophenyl) and acyl group (acetate, propionate and butyrate) binding site of substrate as judged from the progressive lowering of $K_{\mathrm{m}}$ values. The lack of activity with compounds having highly polar moieties (thiocholine of acetyl thiocholine, and phosphate of 1naphthyl and $p$-nitrophenyl esters) corroborates the above observation. A similar trend in the hydrolysis of a series of nitrophenyl esters with the aphid esterase $\mathrm{E}_{4}$ in Myzus persicae is observed (Devonshire and Moores, 1989).

The alternate product inhibition studies carried out with the pure carboxylesterase indicaled the ordered release of products, alcohol (1-naphthol) first followed by acid (butyrate). The random release of the products is ruled out in the present study. The product inhibition patterns agree with the Uni-Bi kinetic scheme, with alcohol as the leading product (Hofstee, 1972). Activation observed at low concentrations of $p$-nitrophenol may be due to the direct reaction of the nucleophilic alcohol with acyl-enzyme intermediate (Junge and Heymann, 1979; Farb and Jencks, 1980) to generate the corresponding aliphatic ester and results in the release of the free enzyme as reported for other esterases.

The homogeneity of the purified carboxylesterase was established by native PAGE, IEF and SDS-PAGE. The results of molecular weight determination obtained by SDS-PAGE and gel-filtration indicate the presence of two equal subunits held together by non-covalent forces. The subunit nature of the midgut carboxylesterase is further confirmed by gel-filtration in the presence of $8 \mathrm{M}$ urea, which gave a molecular weight corresponding to that obtained on SDS-PAGE. The carboxylesterase from the grasshopper, Locusta migratoria was found to contain two unequal subunits which were held together by 


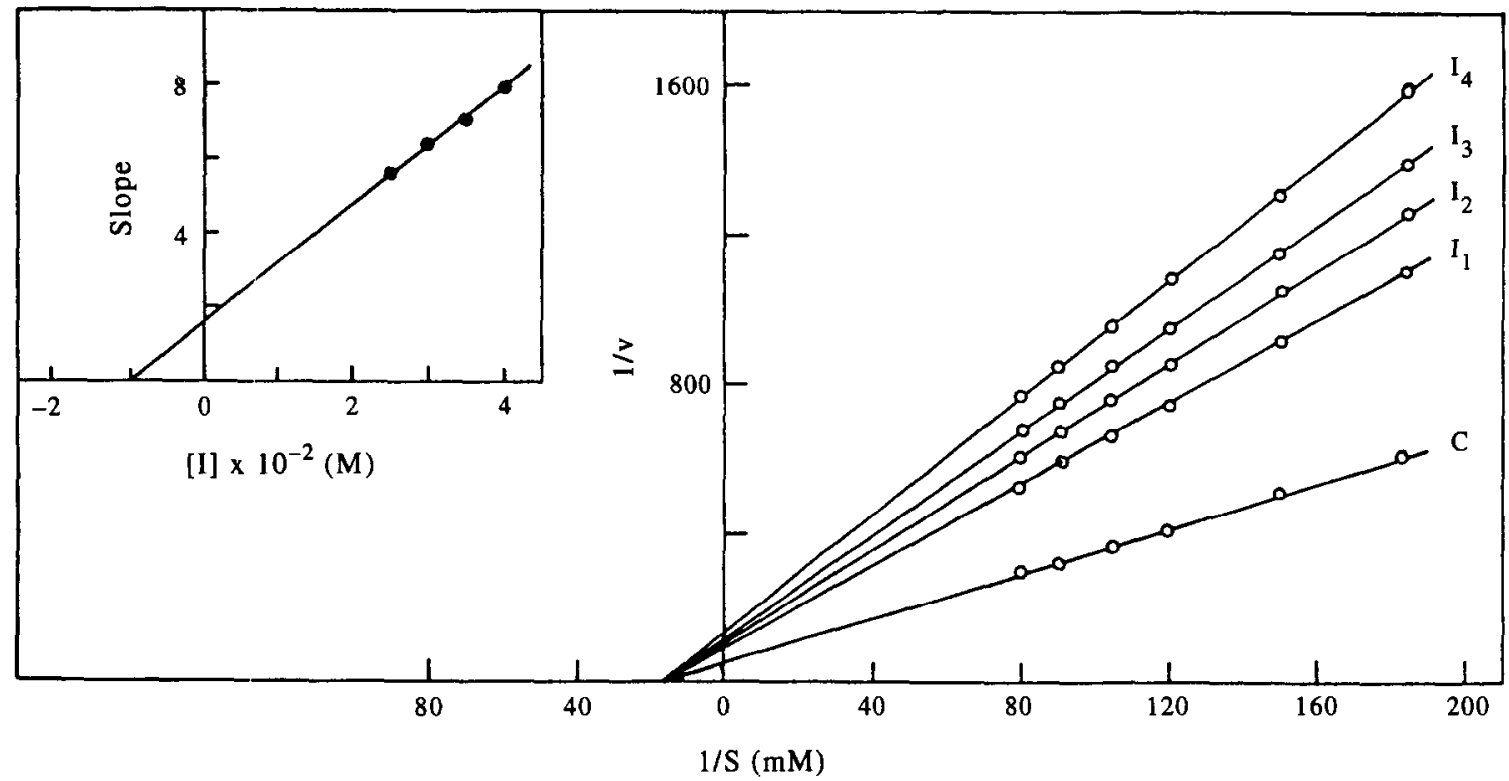

FIGURE 9. LB plots for the carboxylesterase using 1-naphthyl butyrate as substrate in the presence of $p$-nitrophenol. (C) Without $p$-nitrophenol; $\left(I_{1}\right)$ with $0.02 \mathrm{M} p$-nitrophenol; $\left(I_{2}\right)$ with $0.025 \mathrm{M} p$-nitrophenol; $\left(I_{3}\right)$ with $0.03 \mathrm{M} p$-nitrophenol; and $\left(I_{4}\right)$ with $0.035 \mathrm{M} p$-nitrophenol.

disulphide bonds (Koopmanschap and deKort, 1989). It is interesting to note that the activity resided in the smaller subunit. In contrast, the carboxylesterase of the termite Odentotermes horni had two equal subunits linked by disulphide bonds (Sreerama and Veerabhadrappa, 1991) and both the subunits were essential for enzyme activity. However, in the case of silkworm midgut enzyme, which is a non-covalently linked homodimer, the individual subunits obtained by gel-filtration in the presence of $8 \mathrm{M}$ urea exhibited only $10 \%$ esterase activity. Even the removal of $8 \mathrm{M}$ urea by dialysis or gelfiltration on Sephadex G-10 did not increase the activity, indicating the inability of the individual subunits to associate to acquire the native conformation. It requires further investigation to understand the nature of folding and association of each subunit in this particular protein.

Most of the carboxylesterases studied so far, have low $\mathrm{p} I$ values and contain large proportions of acidic amino acids (Scott and Zerner, 1975; Pen et al., 1986; Sobek and Gorisch, 1989; Merryweather et al., 1990, Sreerama and Verrabhadrappa, 1991). The same is also true for the midgut carboxylesterase of the silkworm larvae, B. mori, which exhibited a low $\mathrm{p} I$ value. In addition, the carboxylesterase had a very high content of hydrophobic amino acids. The enzyme was found to be lacking in proline and tryptophan residues, unlike the other insect and plant carboxylesterases (Upadhya et al., 1985; Govindappa et al., 1987). Cysteine residues were found to be absent in B. mori. This is similar to the observation made in the case of the nematode, Caenorhabditis elegans (McGhee, 1987) and the termite, Odentotermes horni (Sreerama and Veerabhadrappa, 1991). However, Pen et al. (1986) have reported one cysteine residue per 100 amino acid residues in two carboxylesterases of Drosphila mojav- ensis, while a single residue of cysteine was reported in Sulfolobus acidocaldarius (Sobek and Gorisch, 1989).

\section{REFERENCES}

Andrews P. (1970) Estimation of molecular size and molecular weights of biological compounds by gel-filtration. In Methods in Biochemical Analysis (Edited by Gilick D.), Vol. 18, p. 1. Wiley, New York.

van Asperen K. (1962) A study of house fly esterases by means of a sensitive colorimetric method. J. Insect Physiol. 8, 401-416.

Davis B. J. (1964) Disc-gel electrophoresis-II method and application to human serum proteins. Ann. N.Y. Acad. Sci. 121, 404-427.

Devonshire A. L. and Moores G. D. (1989) Detoxification of insecticides by esterases from Myzus persicae-is hydrolysis important? In Enzymes Hydrolysing Organophosporus Compounds (Edited by Reiner E., Aldridge W. N. and Hoskin F. C. G.), pp. 180-192. John Wiley and Sons, New York.

Dixon M. and Webb E. C. (1979) In Enzymes 3rd edn, pp. 207-215. Academic Press, London.

Dudman N. P. B. and Zerner B. (1975) Carboxylesterases from pig and ox liver. In Methods in Enzymology (Edited by Lowenstein J. M.), Vol. 35, pp. 190-208. Academic Press, New York.

Ellman G. I. (1959) Tissue sulphydryl groups. Arch. Biochem. Biophys. 82, 70-77.

Farb D. and Jencks W. P. (1980) Different forms of pig liver esterase. Arch. Biochem. Biophys. 203, 214-226.

Fonnum F., Sterri S. H., Aas P. and Johnsen H. (1985) Role of hydrolases in detoxification. Fund. Appl. Toxic. 5, s29-s38.

Gomori G. (1953) Human esterases. J. Lab. Clin. Med. 42, 445-453.

Govindappa T., Govardhan L., Jyothi P. S. and Veerabhadrappa P. S. (1987) Purification and characterization of a carboxylesterase from the latex of Synadenium grantii. Hook, F. J. Biosci. 12, 71-86.

Hoejring N. and Svensmark O. (1976) Carboxylesterases with different substrate specificity in human brain extracts. J. Neurochem. 27, 523-528.

Hofstee B. H. J. (1972) On the substrate activation of liver esterases. Biochem. Biophys. Acta 258, 446-454.

Holmes R. S. and Masters C. J. (1967) Developmental multiplicity and isozyme status of avian esterases. Biochem. Biophys. Acta 132, 379-399. 
Hunter R. L. and Markert C. L. (1957) Histochemical demonstration of isozymes separated by zone electrophoresis in starch gels. Science 125, 1294-1295.

Junge W. and Heymann E. (1979) Characterization of the isoenzymes of pig liver carboxylesterase. II. Kinetic studies. Eur. J. Biochem. 95, 519-525.

Junge W. and Krisch K. (1975) The carboxylesterases/amidases of mammalian liver and their possible significance. CRC Crit. Rev. Toxic. 3, 371-434.

Koopmanschap $\Lambda$. B. and deKort C. A. D. (1989) Carboxylesterases of high molecular weight in the haemolymph of Locusta migratoria. Experientia. 45, 327-330.

Krisch K. (1971) Carboxylester hydrolases. In The Enzymes (Edited by Boyer P. D.), Vol. 5, pp. 43. Academic Press, New York.

Kunitz M. (1947) Crystalline soybean trypsin inhibitor. II. General properties. J. Gen. Physiol. 30, 291-310.

Laemmli U. K. (1970) Cleavage of structural proteins during the assembly of the head of bacteriophage $\mathrm{T}_{4}$. Nature 227, 680-685.

Lowry O. H., Rosebrough N. J., Farr A. L. and Randall R. J. (1951) Protein measurement with the Folin phenol reagent. J. Biol. Chem. 193, 265-275.

McGhee J. D. (1987) Purification and characterization of a carboxylesterase from the intestine of the nematode $C$. elegans. Biochemistry 26, 4101-4107.

Merryweather A. T., Crampton J. M. and Townson H. (1990) Purification and properties of an esterase from the organophosphateresistant strain of mosquito, Culex quinquefasciatus. Biochem. $J$. 266, 83-90.

Meyers D. K. (1960) In The Enzymes. Carboxyl Ester Cleavage (Survey), 2nd edn (Edited by Boyer P. D., Lardy H. and Mybrack K.). Vol. 4, pp. 475-483. Academic Press.

Moore S. and Stein W. H. (1963) Amino acid composition of proteins. In Methods in Enzymology (Edited by Lowenstein J. M.), Vol. 6, pp. 819-831. Academic Press, New York.

Morikawa M., Inoue M. and Tsuboi M. (1976) Substrate specificity of carboxylesterase (E.C. 3.1.1.1) from several animals. Chem. Pharm. Bull. 24, 1661-1664.

Oppenoorth F. J. (1985) Biochemstry and genetics of insecticidal resistance. In Comprehensive Insect Physiology: Biochemistry and Physiology (Edited by Kerkut G. S. and Gilbert L. G.), Vol. 12, 731 pp. Pergamon Press, New York.

Ornstein L. (1964) Disc-gel electrophoresis-I method and application to human serum proteins. Ann. N.Y. Acad. Sci. 121, 321-349.
Pen J., Beeumen J. V. and Beintema J. J. (1986) Structural comparison of two esterases from Drosophila mojavensis isolated by immunoaffinity chromatography. Biochem. J. 238, 691-699.

Pharmacia (1982) Isoelectricfocusing: Principles and Methods, pp. 64 68. Pharmacia Fine Chemicals AB, Upsalla, Sweden.

Rennert O. M. (1967) Disk electrophoresis of acid mucopolysaccharides. Nature 213, 1133.

Scott K. and Zerner B. (1975) Carboxylesterases (E.C. 3.1.1.1). Amino acid composition of liver carboxylesterases. Can. J. Biochem. 53 , 561-564.

Siddalinga Murthy K. R. (1991) Ph.D., Thesis, Bangalore University, Bangalore, India.

Sobek H. and Gorisch H. (1989) Further kinetic and molecular characterization of an extremely heat stable carboxylesterase from the thermoacidophilic archaebacterium, Sulfolobus acidocaldarius. Biochem. J. 261, 993-998.

Sreerama L. and Veerabhadrappa P. S. (1991) Purification and properties of carboxylesterases from the midgut of the termite Odentotermes horni. Insect Biochem. 21, 833-844.

Upadhya G. A., Govardhan L. and Veerabhadrappa P. S. (1985) Purification and properties of a carboxylesterase from germinated finger millet (Eleusine coracana. Gaertn). J. Biosci. 7, 289-301.

Veerabhadrappa P. S., Sara Rani M. and Shadaksharaswamy M. (1980) Purification and properties of an esterase from Haltica caerulea. Ind. J. Biochem. Biophys. 17, 186-190.

Versterberg O., Hansen L. and Sjosten A. (1977) Staining of proteins after isoelectricfocusing in gels by new procedures. Biochem. Biophys. Acta. 491, 160-166.

Walker C. H. and Mackness M. I. (1983) Esterases: problems of identification and classification. Biochem. Pharmac. 32, 3265-3269.

Wringley C. W. (1969) Iso-electrofocusing, Vol. 29, p. 1. Shandon Instrument Applications.

Acknowledgements - We thank Dr L. Govardhan and Dr N. H. Manjunath, Department of Chemistry, Central College, Bangalore, for their critical reviewing of the manuscript and constant advice. We wish to thank Dr D. Rajagopal Rao, Biochemistry Division, Central Food Technological Research Institute, Mysore, for help in amino acid analysis. We wish to acknowledge the gift of some organophosphorus inhibitors used in this study by Pesticide and Industrial Chemical Repository, MD-8, Research Triangle Park, North Carolina, U.S.A. and Ciba-Geigy Ltd, Basel, Switzerland. 